TE DEUM: Jurnal Teologi dan Pengembangan Pelayanan

Volume 10, Nomor 2 (Juni 2021): 139-160

ISSN 2252-3871 (print), 2746-7619 (online)

http://ojs.sttsappi.ac.id/index.php/tedeum/index

DOI: https://doi.org/10.51828/td.v10i2.34

\begin{tabular}{|l|l|l|}
\hline Submitted: $29-12-2020$ & Accepted: 3-5-2021 & Published: 25-6-2021
\end{tabular}

\title{
SUMBANGSIH PEMIKIRAN POSKOLONIAL BAGI WAWASAN MISI INJILI
}

\author{
Carmia Margaret \\ Mahasiswi Program Studi Magister Teologi STT SAAT, Malang \\ carmia.margaret95@gmail.com
}

\section{ABSTRACT}

This paper addresses a question: what postcolonial thought has to do, if any, to the enrichment of evangelical missional worldview? The presupposition acknowledged is that evangelicals already have such a complete and comprehensive missional worldview, but it is often not holistic in its missional practice. Through literature research, it was found that postcolonial ideas can contribute to the evangelicals missional worldview, in terms of sharpening its missional awareness, expanding its mission coverage and missional engagement, developing a vernacular hermeneutic, and promote the equalization between the evangel and the evangelized. This contribution can be elaborated from some main concerns of postcolonialism, namelyits rejection to domination and binary and its search of the bybridity. However, the idea of postcolonialism itself still needs to be evaluated, so that it will not necessarily become a new colonialism as it criticizes.

Keywords: postcolonialism, mission, evangelical, domination, binary.

\section{ABSTRAK}

Artikel ini membahas sebuah pertanyaan: apa sumbangsih pemikiran poskolonial jika ada bagi pengayaan wawasan misi injili? Prasuposisi (praanggapan) yang dimiliki adalah bahwa sejatinya kaum injili sudah memiliki wawasan misi yang utuh dan komprehensif tetapi dalam praktiknya seringkali tidak holistik. Melalui penelitian kepustakaan, ditemukan bahwa gagasan poskolonial dapat memberi sumbangsih bagi wawasan misi injili dalam hal penajaman kesadaran misional, perluasan cakupan misi dan keterlibatan misional, pengembangan hermeneutika orang lokal dan penyetaraan antara yang menginjili dan yang diinjili. 
Sumbangsih ini dapat dielaborasi dari keprihatinan utama gagasan poskolonial yang ingin menghapuskan dominasi, menghapuskan biner dan mengupayakan peleburan identitas. Akan tetapi gagasan poskolonial itu sendiri tetap perlu dicermati agar tidak serta-merta menjadi kolonialisme baru sebagaimana yang dikritisinya sendiri.

Kata-kata kunci: poskolonial, misi, injili, dominasi, biner.

\section{PENDAHULUAN \\ POSKOLONIALISME DAN MISI INJILI}

Poskolonialisme merupakan sebuah teori kritis yang sedang populer hari ini. ${ }^{1}$ Teori ini lahir dari perjumpaan post-strukturalisme dan marxisme. ${ }^{2}$ Intensi utamanya adalah untuk membongkar pengaruh kolonialisme yang destruktif dan refresif serta lebih banyak memberi ruang bagi suara-suara terpinggirkan untuk mencapai liberasi dan transformasi yang utuh. Dengan latar belakang dan intensi demikian, teori ini mendapatkan sambutan hangat dari mereka yang dianggap minoritas, terbungkam dan terpinggirkan sebagai sebuah semangat perlawanan dan penyetaraan. Namun di saat yang sama teori ini juga seringkali dipandang negatif sebagai sebuah gerakan yang penuh prasangka, oposisi dan anti otoritas.

Terlepas dari kesan positif dan negatif yang disematkan kepadanya, mulai bermunculan pendekatan hermeneutika dan wacana berteologi Indonesia yang mencoba menggunakan atau menginteraksikan pendekatan poskolonial dalam isu-isu khusus yang dibahasnya. Singgih pada 2009 telah menerbitkan sebuah artikel tentang pembacaan surat Roma dari lensa poskolonial sebagai salah satu alternatif hermeneutika konstruktif dalam konteks Indonesia paska-reformasi. ${ }^{3}$ Mamahit, misalnya dalam

'Dalam tulisan ini, terminologi "poskolonialisme" dipakai bergantian dengan: "gagasan poskolonial," "pemikiran poskolonial," "ide poskolonial," dan sebutan-sebutan serupa lainnya yang mengacu pada makna yang sama. Dalam literatur-literatur Indonesia sendiri terdapat juga variasi penyebutan: "pascakolonial." Terminologi "poskolonial" dipilih di sini, mengacu pada sebutan umum dalam bahasa Inggris: postcolonial.

${ }^{2}$ Leela Gandhi, Postcolonial Theory: A Critical Introduction (London: Allen \& Unswin, 1998), 23-30.

${ }^{3}$ Emmanuel Gerrit Singgih, "Karl Barth, Robert Jewett and the Context of Reformation in Present-Day Indonesia," Asia Journal of Theology 23, no. 1 (2009): 111-22; Daniel K. Listijabudi, "Pembacaan Alkitab Liberatif, Kontekstual, Postkolonial (Kisi-Kisi Sederhana, Kunci Heuristik Dan Contohnya)," in Meretas Diri, Merengkuh Liyan, Berbagi Kehidupan, ed. Paulus S. Widjaja and Wahju S. Wibowo (Jakarta: BPK Gunung Mulia, 2020), 3-24. Kolega satu almamater Singgih yang juga mengusulkan pendekatan tafsir Alkitab poskolonial adalah Daniel K. Listijabudi. 
presentasinya pada Asian Theological Association (ATA) 2017, mengajukan bahwa hermeneutika poskolonial dapat digunakan dalam metodologi berteologi injili khususnya dalam pengertian injili yang sangat luas. ${ }^{4}$ Sumbangsih terkini lahir dari Hutagalung, seorang sarjana teologi sistematika asal Indonesia yang baru saja menuntaskan disertasinya di Garrett-Evangelical Theological Seminary dalam topik pneumatologi poskolonial. ${ }^{5}$ Meskipun beragam penelitian ini seolah mewakili spektrum tertentu dalam kaitan penerimaan dan kesetujuannya dengan gagasan poskolonial, tetapi hampir seluruhnya sependapat bahwa teori poskolonial adalah alternatif yang baru, segar, konstruktif dan dapat menjadi sebuah gagasan operatif serta memberikan sumbangsih tersendiri dalam konteks berteologi di Indonesia.

Berdasarkan lanskap ini alangkah menarik untuk bertanya: adakah pengaruh atau sumbangsih yang dapat diberikan oleh pemikiran poskolonial terhadap misi injili Indonesia? Pertanyaan ini menjadi genting dan vital khususnya di tengah tiga latar. Pertama, elaborasi gagasan poskolonial dalam wacana teologi lebih banyak dilakukan oleh para sarjana ekumenikal ketimbang evangelikal meskipun bukan berarti nihil. Kedua, interaksi poskolonial dan wacana teologi sejauh ini lebih banyak terjadi di lahan hermeneutika biblika dan teologi (sistematika) tetapi tidak banyak dalam misiologi. Ketiga, adanya stigma umum bahwa misi injili di Indonesia merupakan warisan dari para penjajah Barat (kolonialisasi) bahkan masih mengandung unsur-unsur kolonialisme sampai sekarang, sehingga tidak benar-benar dapat menjadikan kekristenan sebagai "keyakinan lokal" yang operatif dan transformatif. ${ }^{6}$

Tulisan ini akan mencoba melihat sumbangsih yang mungkin dapat diberikan oleh pandangan poskolonial terhadap wawasan dan praksis misi Injili Indonesia hari ini. Untuk itu, akan terlebih dahulu diperlihatkan

${ }^{4}$ Ferry Y. Mamahit, "Postcolonial Reading of the Bible: An Asian Evangelical Friend or Foe?" (Malang, 2017); Ferry Y. Mamahit, "Studi Pascakolonial Dan Evangelikalisme: Kawan Atau Lawan?," Theovlogy Channel, 2019, https://www.youtube.com/watch?v=7faybR4gwbg. dalam kanal diskusi teologi "Theovlogy," Mamahit memperluas cakupan studi interdisipliner teologi-poskolonial bukan hanya pada hermeneutika tetapi juga pada cabang studi teologi lainnya

${ }^{5}$ Toar Banua Hutagalung, "Dishoming Space: Toward an Embodied Decolonial Pneumatology" (Garret-Evangelical Theological Seminary, 2021); Toar Banua Hutagalung, "Antropologi Teologis Melalui Perspektif Poskolonial," Theovlogy Channel, 2020, https://www.youtube.com/watch?v=Xy4XVJ12aq0.

'Benyamin Fleming Intan, "Misi Kristen Di Indonesia: Kesaksian Kristen Protestan," Societas Dei: Jurnal Agama Dan Masyarakat 2, no. 2 (October 24, 2017): 325-65, https://doi.org/10.33550/sd.v2i2.21. 
beberapa sketsa atau potret misi injili hari ini. Kemudian akan dipaparkan secara ringkas mengenai pengertian dan ide-ide pokok dalam gagasan poskolonial untuk dicari kemungkinan-kemungkinan sumbangsih yang dapat diberikannya. Terakhir, akan diberikan semacam catatan yang perlu dipikirkan lebih lanjut berkaitan dengan dinamika interaksi ide poskolonial dan misi injili.

\section{Metode PENELITIAN}

Metode penelitian yang digunakan dalam tulisan ini adalah penelitian literatur. Penulis membaca dan menganalisis sumber-sumber pustaka tentang wawasan misi injili dan gagasan poskolonial kemudian mengontruksi dan menyintesanya untuk menjawab pertanyaan riset yang diajukan.

\section{MENGGURAT POTRET MISI INJILI HARI INI}

Bukan tempatnya di sini untuk mendiskusikan panjang lebar tentang apa dan siapa yang disebut "kaum injili" itu, tetapi penting untuk tetap menyamakan persepsi tentang identitas kelompok injili yang akan dibicarakan. ${ }^{7}$ Pakar sejarah gereja Indonesia, Aritonang mengemukakan kerumitan tertentu mengenai identifikasi injili di Indonesia:

"Di antara sekitar 275 organisasi protestan di Indonesia, ditambah dengan 400-an yayasan, paling kurang setengah (jika tidak dapat dikatakan semua) mengaku sebagai gereja dan yayasan yang injili. Di dalamnya termasuk sejumlah gereja yang masuk kategori arus utama (misalnya GMIM, GMIT, GMIH, GMIST, GKI Irja, dsb., di mana huruf "I" merupakan singkatan dari 'injili' [sic]) dan juga sebagian besar gereja Pentakostal. Dengan melihat kenyataan ini kita disadarkan bahwa istilah 'injili' mengandung beberapa pengertian dan kerumitan, yang bisa (bahkan sering) membingungkan." 8

7Brian Harris, "Beyond Bebbington: The Quest for Evangelical Identity," Churchman 122, no. 3 (2008): 201-20; Chandra Wim, “The Chronicles of Evangelicalism: Sebuah Pengantar Historis Terhadap Gerakan Evangelikal," Veritas : Jurnal Teologi Dan Pelayanan 12, no. 2 (October 1, 2011): 187-91, https://doi.org/10.36421/veritas.v12i2.249.

8Jan S. Aritonang, Berbagai Aliran Di Sekitar Gereja (Jakarta: BPK Gunung Mulia, 1996), 227-28. Tentu saja perkembangan Injili di Indonesia juga tidak dapat dilepaskan dari berdirinya berbagai sekolah teologi, lembaga misi, dan pelayanan-pelayanan mahasiswa atau paragereja. 
Dari realita kompleksitas pengidentifikasian kaum injili di Indonesia ini, agaknya lebih tepat untuk mencari tahu esensi atau "apa" yang disebut dan menjadi keunikan dari kaum injili itu sendiri daripada mendaftarkan "siapa" yang termasuk injili dan yang bukan.

Definisi injili yang paling umum dan berterima secara luas datang dari Bebbington. Ia mendefinisikan empat ciri khusus (yang sering disebut juga quadrilateral) dari kelompok injili yaitu penekanan pada konversi (pertobatan pribadi), otoritas Alkitab sebagai firman Allah, pentingnya aktivitas penginjilan dan pentingnya karya keselamatan di dalam salib Kristus. ${ }^{9}$ Berkaitan dengan posisi kelompok injili di tengah-tengah aras kekristenan lainnya, Sidharta mengatakan bahwa injili bisa termasuk semua kalangan di luar kelompok liberal, Katolik Roma dan Ortodoks (Timur). ${ }^{10}$ Mengacu pada definisi Bebbington, terlihat bahwa kelompok injili memberikan penekanan pada konversi (pertobatan) pribadi sehingga misi merupakan hal yang krusial dalam keberlangsungan gerakan injili. Hasil pada misi Kristen injili seringkali secara terbatas hanya ditujukan pada kepercayaan pribadi di dalam Kristus dan kesalehan hidup, tetapi seiring perkembangan waktu khususnya melalui Perjanjian Lausanne (1974), Manifesto Manila (1989) dan Komitmen Cape Town (2010) mulai ada perhatian serius untuk melihat misi sebagai proses transformasi manusia dan ciptaan secara utuh. ${ }^{11}$

Tetapi bagaimana realita potret misi injili hari ini? Apakah konsepsi misiologi yang sudah dan terus-menerus digumulkan oleh para teolog dan misiolog, termasuk juga berbagai kongres dan semangat Lausanne telah mewujudnyata, operatif dan transformatif dalam kegerakan (gereja-gereja) injili di Indonesia? Hal ini tidak bisa tidak mengusik pemikiran apalagi di tengah realita bahwa penyebaran kekristenan (injili) di Indonesia dimotori oleh kolonialisme Barat khususnya Eropa untuk misi dan Amerika untuk perkembangan teologi.

${ }^{9}$ David Bebbington, Evangelicalism in Modern Britain: A History from the 1730s to the 1980s (Grand Rapids: Baker, 1989), 2-3.

${ }^{10}$ Leonard Sidharta, "Spiritualitas Injili" (Jakarta, 2017).

11"The Lausanne Covenant," n.d., https://www.lausanne.org/content /covenant/lausanne-covenant\#cov; "The Manila Manifesto," n.d., https://www.lausanne.org/content/manifesto/the-manila-manifesto; "The Cape Town Commitment," n.d., https://www.lausanne.org / content/ctcommitment\#capetown; Ferry Y. Mamahit, "Perjanjian Lausanne 1974: Revitalisasi Missio Dei Evangelikal" (Malang, 2017); Ferry Yefta Mamahit, "Globalisasi, Gereja Injili Dan Transformasi Sosial," Veritas : Jurnal Teologi Dan Pelayanan 6, no. 2 (October 1, 2005): 255-78, https://doi.org/10.36421/veritas.v6i2.151. 
Berdasarkan pengamatan umum terhadap berbagai literatur dan fenomena gerejawi ada setidaknya lima "potret" atau gambaran misi Injili hari ini. Pertama, misi injili cenderung tidak holistik. Hal ini dapat terlihat dari masih maraknya terjadi dualisme antara penginjilan dan humanisasi. Penginjilan dan humanisasi masih ditempatkan dalam posisi either-or, bukan both-and. Kalau pun tidak ditempatkan dalam posisi either-or, masih terdapat kebingungan konsep di dalam misi gereja-gereja injili yang menganggap penginjilan sebagai humanisasi dan humanisasi sebagai penginjilan. ${ }^{12}$ Sejatinya, pemisahan kedua struktur penginjilan dan humanisasi bukanlah paradigma alkitabiah melainkan sebuah kecelakaan sejarah. ${ }^{13}$ Memang gerakan Lausanne telah menekankan keseimbangan antara penginjilan dan humanisasi. Akan tetapi, tetap harus diakui bahwa ruang lingkup gerakan ini masih sangat terbatas pada tataran idealisme, teori dan mungkin hanya berlaku pada mereka yang terpapar gerakan Lausanne. Pertanyaannya: ada berapa banyak gereja injili di Indonesia yang ikut dalam gerakan Lausanne? Atau bahkan berapa banyak gereja injili di Indonesia yang mengatahui tentang gerakan-gerakan Lausanne dan ide-ide pokoknya? Dengan kata lain paradigma dan praksis misi yang holistik belum cukup kokoh terbentuk.

Kedua, misi injili terlihat berjalan dengan "setengah hati." Maksudnya adalah cakupan misi gereja injili masih sangat terbatas dan cenderung terfokus kepada berbagai persoalan internal gerejawi, sehingga misi secara utuh lebih sering diserahkan kepada para mitra gereja (parachurches). Idealnya gereja sebagai agen tunggal misi Allah harus memiliki kapasitas baik sebagai pemodal maupun tenaga ahli sehingga kedua struktur ini dapat bekerjasama dalam mengerjakan misi Allah yang bersifat holistik. ${ }^{14}$ Tentu saja ada gereja-gereja yang sudah mulai memperjuangkan misi yang holistik (penginjilan dan humanisasi), namun sejauh ini masih bisa dapat dikatakan "setengah hati" karena masih ada banyak area yang belum berani atau tidak disentuh seperti persoalan hak asasi, kelas sosial, trauma, politik, kemiskinan, perdagangan manusia, krisis lingkungan hidup dan sebagainya.

12Melba Padilla Maggay, Transformasi Masyarakat: Refleksi Keterlibatan Sosial Kristen, ed. Johan Hasan (Jakarta: Ergon Radix Integrita, 2004), 9-12.

${ }^{13}$ George W. Peters, A Biblical Theology of Missions (Chicago: Moody, 1974), 229.

${ }^{14}$ Orlando E. Costas, The Church and Its Mission: A Shattering Critique from the Third World (Wheaton: Tyndale, 1974), 168-69; Ralph D. Winter, "The Two Structures of God's Redemptive Mission,” Missiology: An International Review 2, no. 1 (January 1, 1974): 121-39, https://doi.org/10.1177/009182967400200109. 
Ketiga, misi injili terlihat menampilkan gambaran elitis dan profesionalitas. Misi dikerjakan secara terbatas hanya oleh kaum cendekia, vokasional atau pemilik sumber daya material (rohaniwan, misionaris, orang-orang yang terdidik secara khusus, pengurus bidang misi dan sebagainya) sehingga mengabaikan panggilan bagi setiap orang percaya untuk menjadi imamat yang rajani. ${ }^{15}$ Gereja juga cenderung mengalihkan panggilan bagi orang percaya untuk "pergi dan menjadikan murid" menjadi "datang dan lihatlah."16 Para elite dan profesional rohani di gereja lebih banyak memotivasi orang percaya untuk membawa orang yang belum mengenal Tuhan untuk "datang dan melihat" atraksi misi yang disedikan di gereja ketimbang dengan sungguh-sungguh memperlengkapi dan mengutus setiap jemaat untuk pekerjaan kudus yang disedikan Tuhan bagi orang percaya yaitu: "pergi dan menjadikan murid" dalam konteks keseharian mereka. ${ }^{17}$

Keempat, terlihat bahwa misi injili tidak atau minim, dalam membangun kontekstualisasi yang seimbang dengan budaya lokal. Keller memaparkan bahwa seringkali gereja dibutakan oleh budaya sehingga tidak dapat melihat titik buta di dalam budaya. ${ }^{18}$ Akibatnya injil seringkali diberitakan dengan satu dari dua kecenderungan antara terlalu mengadaptasi (over-adapt) budaya dengan tidak kritis sehingga berujung pada sinkretisasi atau justru minim adaptasi (under-adapt) dan menolak mentahmentah budaya lokal sehingga hanya mengasilkan legalisme. Kontekstualisasi Injil yang seimbang dan kritis yang masih menjadi tugas berat bagi gereja hari ini khususnya dalam konteks Indonesia. ${ }^{19}$

${ }^{15}$ David Platt, Radical Together (Colorado: Multnomah, 2011), 68-72.

${ }^{16}$ Jared C. Wilson, The Gospel Driven Church: Uniting Church-Growth Dreams with the Metrics of Grace (Grand Rapids: Zondervan, 2019), 150-54. Wilson juga menyebut gereja harus menjadi bukan hanya peoples in place (church building) tetapi juga peoples in places (mengerjakan misi yang inkarnasional di dalam keseharian mereka di manapun mereka berada).

${ }^{17}$ Skye Jethani, Immeasurable: Reflections on the Soul of Ministry in the Age of Church, Inc. (Chicago: Moody, 2017), 44-49; Kent Carlson and Mike Lueken, Renovation of the Church: What Happen When a Seeker Church Discovers Spiritual Formation (Downers Grove: InterVarsity, 2011), 107-8. Yang menyebutkan bahwa gereja harus memperlengkapi dan mengutus jemaatnya untuk mengerjakan misi inkarsional dalam kehidupan sehari-hari mereka di tengah dunia yang membutuhkan injil Kristus.

${ }^{18}$ Timothy Keller, Center Church: Doing Balanced Gospel-Centered Ministry in Your City (Grand Rapids: Zondervan, 2012), 102.

${ }^{19}$ Sam Chan, Evangelism in a Skeptical World: How to Make the Unbelievable News About Jesus More Believable (Grand Rapids: Zondervan, 2018), 135. Menariknya, Paul Hiebert menyebut under-adapt sebagai colonialism contextualization dan over-adapt sebagai uncritical contextualization. 
Terakhir, dalam kelompok injili di Indonesia terlihat minimnya wawasan dunia misional yang sehat. Gereja-gereja masih cenderung masih melihat misi sebagai aktivitas yang dikerjakan bagi Allah ketimbang sebuah keterlibatan dalam misi Allah. Dengan kata lain, gereja sepertinya masih sibuk membangun narasi misinya sendiri misalnya ekspansi pengaruh gereja, pengokohan keberadaan dan signifikansi gereja serta membangun "kerajaannya" sendiri daripada sungguh-sungguh berpartisipasi secara aktif dalam misi Allah yang global dan holistik. ${ }^{20}$ Minimnya wawasan dunia misional yang sehat ini juga menyebabkan kesulitan untuk menemukan gereja-gereja yang mau dan mampu berjejaring dalam semangat kesatuan untuk mengerjakan misi Allah secara global dan holistik.

\section{MEMAHAMI GAGASAN POSKOLONIAL}

Lantas, apakah sebenarnya poskolonialisme itu dan mengapa gagasan ini menarik untuk disimak di tengah krisis misi Injili hari ini? Sebelum mendiskusikannya, perlu terlebih dahulu dipahami bahwa poskolonialisme adalah dunia gagasan yang tidak mudah didefinisikan. ${ }^{21}$ Studi poskolonialisme itu sendiri tersebar dan digunakan dalam banyak ranah keilmuan yang berbeda-beda mulai dari filsafat, teologi, sejarah, antropologi sampai studi seni. Banyak orang keliru memahami poskolonialisme sematamata sebagai sebuah periode setelah berakhirnya kolonialisme. ${ }^{22}$ Kenyataannya poskolonialisme tidak hanya berbicara soal periode waktu tetapi bahkan bisa mencakup segala sesuatu yang merupakan upaya, ideologi, pemikiran atau kesadaran melampaui dan menggugat pengaruh kolonialisme dalam peradaban. ${ }^{23}$ Pengaruh kolonialisme yang dimaksudkan

${ }^{20}$ Keller, Center Church: Doing Balanced Gospel-Centered Ministry in Your City, 255-58.

${ }^{21}$ Danang Kristiawan, "INTERPRETASI ALKITAB POSTKOLONIAL DI ASIA: BELAJAR DARI SUGIRTHARAJAH,” Gema Teologi 33, no. 1 (2009): 1-21, http://journaltheo.ukdw.ac.id/index.php/gema/article/view/33. Istilah poskolonialisme bisa digunakan bergantian dengan teori poskolonial atau gagasan poskolonial.

${ }^{22}$ Kristiawan, "INTERPRETASI ALKITAB POSTKOLONIAL DI ASIA: BELAJAR DARI SUGIRTHARAJAH"; Robertus Wijanarko, "POSKOLONIALISME1 DAN STUDI TEOLOGI Sebuah Pengantar," Studia Philosophica et Theologica 8, no. 2 (2008): 126, https://doi.org/https://doi.org/10.35312/spet.v8i2.102.

${ }^{23}$ Wijanarko, "POSKOLONIALISME1 DAN STUDI TEOLOGI Sebuah Pengantar," 126; Catherine Keller, Postcolonial Theologies: Divinity and Empire (St. Louis: Chalice, 2004), 6; Ivan Sampe Buntu, "Membaca Teks Dalam Pandangan Poskolonial: Catatan Kritis Atas Bacaan Terhadap Teks Kitab Suci," BIA': Jurnal Teologi Dan Pendidikan Kristen Kontekstual 1, no. 2 (December 30, 2018): 179, https://doi.org/10.34307/b.v1i2.46. 
juga beragam dan luas meliputi misalnya segi ekonomi, politik, sosiologi massa, pengetahuan bahkan keagamaan. ${ }^{24}$

Motif utama poskolonialisme adalah untuk menolak dan melawan pengetahuan, persepsi atau kuasa dominan yang bersifat hegemonik untuk atau dengan cara, mengangkat suara-suara dan persepsi dari kelompokkelompok yang non-dominan dan non-mayoritas. ${ }^{25}$ Misalnya jika selama ini kuasa atau pengaruh dominan dalam hampir segala hal di dunia termasuk teologi, datang dari negara Barat dan kebanyakan dicetuskan oleh laki-laki kulit putih, maka poskolonialisme secara intensional mengajak masyarakat untuk menyadari adanya bias hegemonik ini dan kemudian berupaya untuk mengangkat dan mendengar pemikiran dan pengalaman dari kelompokkelompok lain di luar itu misalnya dari negara Timur (Asia, Afrika atau India), perempuan atau gender lain yang diakui serta orang-orang kulit berwarna. Asumsi awal dari teori poskolonialisme adalah bahwa pertama, manusia terperangkap dalam struktur dan sejarah yang dibentuk sedemikian rupa oleh pemilik kuasa atau dalam hal ini bisa juga penjajah (kolonial). ${ }^{26}$ Kedua, bahwa meskipun kolonialisme secara geografis, politis dan periodik telah berakhir, tetapi "sisa-sisa" dampaknya masih terasa di dalam struktur berpikir dan kelas sosial masyarakat. ${ }^{27}$ Kedua hal ini menyebabkan ada kelas masyarakat yang tertindas, terbungkam dan tidak diakui atau dihargai keberadaan dan pengaruhnya secara penuh. Maka poskolonialisme mengusulkan untuk membongkar struktur kuasa yang membelenggu dan dengan demikian membebaskan kaum yang selama ini tidak terdengar. Pertanyaan heuristiknya ialah: Apa dan di mana letak dominasi kuasa dalam teks ini? Adakah dan bagaimanakah kita sebaiknya membangkitkan dan mendengar suara-suara dari "pinggir" dan dari "bawah" yang mungkin selama ini terbungkam oleh kuasa?

${ }^{24}$ Yani Kusmari, "Teori Poskolonial: Suatu Kajian Tentang Teori Poskolonial Edward W. Said,” Departemen Pendidikan Sejarah, 2019, 1-14.

25Kristiawan, "INTERPRETASI ALKITAB POSTKOLONIAL DI ASIA: BELAJAR DARI SUGIRTHARAJAH," 2; Buntu, "Membaca Teks Dalam Pandangan Poskolonial: Catatan Kritis Atas Bacaan Terhadap Teks Kitab Suci," 179; Mamahit, "Postcolonial Reading of the Bible: An Asian Evangelical Friend or Foe?," 2.

${ }^{26}$ Mamahit, "Postcolonial Reading of the Bible: An Asian Evangelical Friend or Foe?," 2-3.

${ }^{27}$ Lebih lanjut, ada pula "kolonialisme baru" yang berupa dominasi struktur ekonomi suatu negara atau kelompok masyarakat oleh negara lain. Lih. Kristiawan, "INTERPRETASI ALKITAB POSTKOLONIAL DI ASIA: BELAJAR DARI SUGIRTHARAJAH," 2; Gading Sianipar, "Mendefinisikan Pascakolonialisme?: Pengantar Menuju Wacana Pemikiran Pascakolonialisme," in Hermeneutika Pascakolonial, ed. Mudji Sutrisno and Hendar Putranto (Yogyakarta: Kanisius, 2004), 9-10. 
Poskolonialisme sebagai sebuah teori kritis dikenal melalui tiga "pemain utama" yaitu Said, Spivak dan Bhaba. Ketiganya menunjukkan cara kerja poskolonialisme sebagai sebuah strategi pembacaan di dalam studi teks-teks lihnteratur dan kultural khususnya Barat untuk menyelidiki dan membongkar kaitan antara pengaruh kuasa dan pengetahuan. ${ }^{28}$ Meskipun berangkat dari sudut pandang yang mirip tetapi ketiganya memiliki dimensi perhatian khusus yang berbeda-beda. Said lebih berfokus pada apa yang disebutnya sebagai orientalisme yaitu bukti-bukti dominasi segala sesuatu dari Barat kepada yang bukan Barat, Spivak lebih menekankan pentingnya mendengar suara subaltern atau kelompok yang termarginalisasi sementara Bhabha menekankan hibriditas atau percampuran dan ketiadaan identitas tunggal sebagai realitas keberadaan. ${ }^{29}$

Ada beberapa nilai utama yang ditekankan oleh poskolonialisme dan muncul dalam hampir semua literaturnya. Pertama, poskolonialisme memiliki semangat untuk menolak oposisi biner. Oposisi biner yang dimaksud adalah pembagian ketat antara kaum penguasa dan yang tidak punya kuasa, penindas dan tertindas, ilmuwan dan awam, bangsawan dan jelata, laki-laki dan perempuan dan sebagainya. Poskolonialisme menolak pembagian cara berpikir seperti ini dan justru mencampurkan keduanya menjadi sebuah hibriditas yang kemudian direngkuh menjadi sebuah identitas baru lepas dari dikotomi biner sebelumnya.

Kedua, poskolonialisme juga menyuarakan penolakan terhadap dominasi. Dominasi terjadi ketika ada gagasan, oknum atau pengaruh tertentu yang menetapkan diri sebagai standar utama dan preferensi yang harus diikuti. Misalnya saja dalam pendidikan, poskolonialisme menolak jika dikatakan bahwa kebenaran tertinggi hanya ada pada guru atau pada buku sejarah primer. Poskolonialisme akan mencoba menyusuri jejak-jejak suara yang tersembunyi di pinggir, di belakang atau di bawah dan membawanya ke tengah, ke depan dan ke atas panggung suara dan kuasa. Meminjam ide Spivak, poskolonialisme mencari tahu sub-altern dalam suatu konteks dan berupaya dengan sengaja untuk mendengarkan mereka. ${ }^{30}$

Ketiga, poskolonialisme juga merupakan sebuah upaya terusmenerus untuk membangun identitas. Identitas itu sendiri mencakup

\footnotetext{
Foe?," 3.

${ }^{28}$ Mamahit, "Postcolonial Reading of the Bible: An Asian Evangelical Friend or

${ }^{29}$ Disarikan dari Datta G. Sawant, "Perspectives on Postcolonial Theory: Said, Spivak and Bhabha," 2015, 1-7, https://www.researchgate.net/publication/271633479.

${ }^{30}$ Gayatri Chakravorty Spivak, "Can the Subaltern Speak?: Speculations on Widow Sacrifice,” n.d., http://abahlali.org/files/Can_the_subaltern_speak.pdf.
} 
gender, ras, suku, warna kulit, konteks lokal, kelas ekonomi dan unsurunsur pembentuk kedirian lainnya. Poskolonialisme akan mendorong semua individu atau kelompok masyarakat untuk menolak pelekatan identitas dari pihak lain (labelling) tetapi seharusnya justru menyadari, mengenali dan mengonstruksi identitasnya sendiri. Menariknya, poskolonialisme juga beranggapan bahwa tidak ada identitas yang benarbenar tunggal atau justru kita semua berada dalam percampuran atau hibriditas. Identitas bercampur (bybrid) ini adalah sebuah identitas baru yang perlu dikenali, direngkuh dan dihargai sepenuhnya dalam dinamika sistem. ${ }^{31}$

Terakhir, poskolonialisme mengedepankan ide tentang perjumpaan dengan yang lain atau sering diistilahkan dengan Liyan (The Other). Adalah sebuah kecenderungan dari cara berpikir kolonialisme untuk menempatkan sesama manusia sebagai objek yang harus dikenal untuk kemudian ditaklukkan. ${ }^{32}$ Poskolonialisme menolak cara berpikir seperti ini dan mengusulkan bahwa siapa pun yang berbeda dari kelompok tertentu harus dipandang sebagai subjek seutuhnya dan bukan objek, apalagi objek yang lebih rendah atau lebih salah. Bahkan, poskolonialisme menyumbangkan sebuah kesadaran bahwa semua manusia pada dasarnya adalah Liyan yang selalu terlibat dengan perjumpaan dengan sesama Liyan lainnya.

\section{KONTINUITAS DISKONTINUITAS DAN SUMBANGSIH PEMIKIRAN POSKOLONIAL BAGI WAWASAN MISI INJILI}

Ada kontinuitas antara pemikiran poskolonial dan cita-cita wawasan misi injili khususnya yang tercermin dalam gerakan Lausanne. Pertama, keduanya sama-sama menekankan bahwa Injil bersifat transformatif dan liberatif. Injil tidak hanya berbicara mengenai keselamatan spiritual. ${ }^{33}$ Meskipun berita tersebut tetap yang utama, tetapi juga berpengaruh pada transformasi sosial, ekonomi, politis dan kultural. Injil tidak pernah dimaksudkan untuk berhenti hanya di dalam tembok gereja tetapi juga memengaruhi dan mengubahkan komunitas masyarakat yang lebih luas.

${ }^{31}$ Mudji Sutrisno, "Diri Dan 'The Other," in Hermeneutika Pascakolonial: Soal Identitas (Yogyakarta: Kanisius, 2004), 27-30; Daniel K. Listijabudi, Bergulat Di Tepian: Pembacaan Lintas Tekstual Dua Kisah Mistike (Dewa Ruci \& Yakub Di Yabok) Untuk Membangun Perdamaian (Jakarta: Gunung Mulia, 2019), 6-8.

32Sutrisno, "Diri Dan 'The Other," 27-30.

${ }^{33}$ Yohanes Hasiholan Tampubolon, "Misi Gereja Di Era Kapitalisme Global: Eksplorasi Pelayanan Misi Yesus," Societas Dei: Jurnal Agama Dan Masyarakat, 2020, https://doi.org/10.33550/sd.v7i2.137. 
Kedua, proses penginjilan harus berjalan secara holistik dan tidak dikotomis antara penginjilan dan humanisasi. Berita Injil adalah cara sekaligus alat ilahi untuk menjadikan manusia kembali kepada pemenuhan tujuan penciptaannya yang semula dan tidak ada metode humanisasi terbaik selain memperkenalkan orang kepada Kristus. Bila gagasan ini dapat dihayati dan direngkuh secara penuh, maka penginjilan gereja tidak lagi semata-mata pragmatis atau terapeutik, tetapi dapat benar-benar menjadi transformatif dan holistik.

Akan tetapi, ada juga diskontinuitas yang terjadi khususnya antara ide poskolonial dengan realita praksis misi injili. Dari lima potret yang telah dipaparkan sebelumnya, salah satu miskonsepsi yang sering tidak disadari adalah posisi hierarkis antara pihak pekabar Injil dengan penerima Injil atau orang yang melayani dan yang dilayani. Alangkah jamak orang yang menginjili merasa sudah lebih superior secara intelektual, spiritual dan moral, dibandingkan orang yang diinjili. Penerapan pelayanan Injil yang demikian sadar atau tidak akan sangat rentan berubah menjadi opresi, dominasi, agresi bahkan eksploitasi kuasa dalam konteks sosial atas nama religius dan kebenaran.

Kemudian harus diakui bahwa poskolonialisme sebagai teori kritis postmodern telah melangkah lebih maju untuk berdekatan dengan konteks dan pergerakan zaman. Agar tetap terjaga vitalitas dan relevansinya, rupanya wawasan misi injili juga perlu mendengarkan sumbangsih dari poskolonialisme khususnya dalam hal sosial dan kultural. Berikut ini beberapa sumbangsih yang dapat didengar oleh misiolog injili dari poskolonialisme. Tentu saja interaksi ini harus berlangsung secara seimbang, terjaga ketegangannya dan tidak ada yang akhirnya saling tarikmenarik atau berat sebelah. Jangan sampai dogmatika injili hanya membaptis gagasan poskolonialisme atau sebaliknya poskolonialisme mendekonstruksi wawasan misi injili. Penting untuk menjaga hibriditas interaksi ini sebagaimana yang digaungkan oleh motif poskolonialisme itu sendiri.

\section{PENAJAMAN KESADARAN Misi INJILI}

Pertama, pendekatan poskolonial dapat menajamkan kesadaran misi injili. Pendekatan poskolonial memberikan nilai yang tinggi bagi semua kalangan, suku, bangsa dan bahasa. Ini sebenarnya selaras dengan mandat penyebaran Injil ke seluruh bumi tetapi dalam praktiknya mandat Injil ini diejawantahkan secara terbatas ke daerah dominan, negara maju atau suku- 
suku tertentu saja. Maka dalam hal ini, poskolonialisme kembali mengingatkan bahwa misi injili seharusnya tidak diawali oleh urgensi bagi satu kaum/bangsa tertentu saja namun diawali oleh sebuah kesadaran bahwa semua kaum dan bangsa membutuhkan Injil.

Selain itu, pendekatan poskolonial menolong kaum injili untuk menyadari tidak ada kaum atau bangsa yang dapat dikatakan "sudah selesai diinjili." Pendekatan poskolonial mendorong kaum injili untuk peka dan benar-benar mengalami perjumpaan dan melakukan interaksi dengan berbagai kelompok yang "diinjili." Penginjilan tidak bisa lagi dipandang sebagai daftar tugas yang hanya perlu diselesaikan dan dapat ditinggalkan jika sudah dilakukan. Penginjilan justru merupakan sebuah momen pertemuan dan dialog dengan Liyan. Dengan demikian penginjilan tidak menjadi usaha untuk semata-mata menempatkan nilai baru kepada pribadi yang baru dijumpai tetapi justru menjadi sebuah usaha untuk memahami konteks dari pribadi yang baru dijumpai. Hasilnya akan tercipta sebuah ruang bagi kaum injili dan Liyan untuk berinteraksi di dalam pembangunan identitas masing-masing.

\section{Perluasan CaKupan Misi dan Keterlibatan Misional}

Tidak hanya mengedepankan pengenalan akan kaum/bangsa yang berbeda, pendekatan poskolonial juga mengedepankan pengenalan akan bidang-bidang spesifik dalam kehidupan masyarakat. Sugirtharajah berkata, "Postcolonialism involves investigation into various colonial archives and discussion on a variety of issues ranging from slavery to migration, from gender to ethnic matters." 34 Berdasarkan pernyataan tersebut, dapat disimpulkan bahwa poskolonialisme tidak hanya menyediakan sebuah ruang bagi diskusi mengenai identitas masyarakat dalam konteks religius, tetapi juga ruang bagi isu-isu lain seperti ekonomi, politik, sosial, budaya, seni, pendidikan, bisnis dan lainnya. Dengan demikian upaya penginjilan tidak semata-mata berarti hanya membicarakan isu-isu keagamaan (Kristen) tetapi juga upaya transformasi semua lini kehidupan manusia. Lahan bermisi juga bukan hanya gereja atau lembaga, kota atau desa, orang kaya atau orang miskin dan anak-anak atau orang tua, tetapi juga berbagai area "sensitif" dan "tersembunyi” yang mungkin tidak terpikirkan sebelumnya. Sebut saja isuisu pemulihan trauma pasca kekerasan politis, isu kemerdekaan tahanan

${ }^{34} \mathrm{R}$. S. Sugirtharajah, The Bible and the Third World: Precolonial, Colonial, and Postcolonial Encounters (Cambridge: Cambridge University Press, 2001), 247. 
politik, sengketa hukum, perdagangan manusia, krisis pendidikan, krisis kesehatan, krisis lingkungan hidup dan sebagainya.

Gagasan ini menunjukkan bahwa penginjilan seyogianya bergerak ke arah yang holistik. Namun di saat yang bersamaan jelas bahwa konsep penginjilan yang demikian tidak mudah dilakukan. Sebagai institusi religius, tentu saja gereja memiliki keterbatasan-keterbatasan tertentu dalam berinteraksi dengan segala bidang kehidupan manusia. Di sini poskolonialisme dapat mengisi ruang kosong dengan mendengarkan semua orang dalam bidang keahliannya masing-masing. Suara yang didengarkan juga bukan hanya suara pendeta, pemimpin usaha, pemilik modal atau profesi-profesi dengan pengaruh tinggi dalam masyarakat tetapi juga suara pekerja rendahan atau "kelas bawah" seperti asisten rumah tangga, supir, pedagang asongan, buruh dan sebagainya. Dengan demikian semua jemaat tanpa terkecuali dapat berpartisipasi dalam misi Allah di bidang mereka masing-masing. Keterlibatan seluruh jemaat dalam misi Allah ini dapat dimulai dengan membuka ruang bagi penafsiran dan implementasi Kitab Suci dalam seluruh bidang kehidupan. ${ }^{35}$ Tidak ada lagi penafsiran yang "lebih tinggi" dan "lebih rendah" atau "lebih benar" dan "lebih salah" karena semua jemaat sejatinya juga bergumul dengan teks yang sama. Pergumulan dengan teks itu menjadi misional ketika jemaat berhadapan dengan realita dan konteks kehidupan sehari-hari.

\section{KONTEKSTUALISASI INTERAKTIF DAN PENGEMBANGAN HERMENEUTIKA ORANG LOKAL (VERNACULAR HERMENEUTICS) MELALUI TEKS-TEKS BUDAYA LOKAL}

Sebagaimana terlihat dalam potret hari ini, misi injili selalu berhadapan dengan dilema kontekstualisasi. Di satu sisi Injil perlu disampaikan dengan bahasa yang tidak asing bagi budaya penerima tetapi di sisi lain pesan dan kebenaran Injil harus tetap disampaikan secara penuh. ${ }^{36}$ Mengacu kepada kebutuhan kontekstualisasi ini maka keterbukaan dan

${ }^{35}$ Ibid., 178. Di dalam kutipannya, Sugirtharajah melihat bahwa poskolonialisme melahirkan upaya pembacaan dan penafsiran teks Alkitab bagi jemaat (vernacular hermeneutics). Bagi kami, poskolonialisme tidak hanya berpengaruh kepada pembacaan dan penafsiran teks Alkitab, namun juga implementasi dari kebenaran Allah di dalam kehidupan jemaat. Implementasi inilah yang kemudian dapat menimbulkan transformasi dalam kehidupan masyarakat.

36Keller, Center Church: Doing Balanced Gospel-Centered Ministry in Your City, 89-90. Injil harus menarik dan atraktif bagi pendengar, tetapi juga cukup kuat untuk mengusik hati dan mengajak mereka kepada pertobatan. 
kepekaan terhadap budaya lokal menjadi sebuah keniscayaan. Injil tidak dapat diartikulasikan dengan baik jika tanpa keterbukaan dan kepekaan terhadap budaya lokal pendengarnya.

Pendekatan poskolonial khususnya perspektif orientalis, dapat memberikan kontribusi dalam hal keterbukaan terhadap budaya lokal. Perspektif orientalis mengemukakan kritik yang berkonsentrasi pada pemulihan jiwa budaya lokal dari cengkeraman intelektual dan budaya "guru" asing. Asumsi dasarnya adalah bahwa selama ini mungkin ada unsur-unsur warisan budaya lokal yang kemudian diberi persepsi negatif dan kemudian disembunyikan di balik kepentingan kolonialis (atau misionaris Barat). Maka perspektif orientalis menggaungkan semangat untuk kembali mempelajari dan merengkuh teks-teks budaya lokal mulai dari teks cerita rakyat, bahasa maupun tradisi religus lokal. Harapannya budaya lokal dapat lebih ditonjolkan ke muka melampaui budaya Barat yang menyelubunginya.

Kontekstualisasi kritis dan interaktif dibangun ketika teks Kitab Suci dibaca dan disandingkan dengan teks-teks religius kuno. Teks-teks religius tidak dianggap sebagai sesuatu yang sepenuhnya salah atau negatif, tetapi justru menjadi sebuah persiapan bagi pemahaman Injil. ${ }^{37}$ Penginjilan dapat dibangun dengan mencari kesamaan-kesamaan karakter, nilai, peristiwa atau pesan tertentu dalam teks budaya lokal dan teks Kitab Suci atau juga menunjukkan kontinuitas kedua teks dan diskontinuitasnya yang hanya dapat diisi oleh berita Injil. Dengan demikian, kontekstualisasi di sini tidak hanya semata-mata terjadi dalam tataran praktis tetapi dalam tataran wawasan dunia (worldview) budaya pendengar. Kemudian, teks Kitab Suci juga dapat menjadi teks yang akhirnya sangat dekat dan relevan bagi konteks kehidupan dan formasi iman orang lokal pasca-penginjilan.

${ }^{37}$ Contoh pembacaan seperti ini dilakukan misalnya oleh Krishna Mohan Banerjea (1813-85), seorang Bengali yang bertobat menjadi Kristen dan menulis buku The Arian Witness. Banerjea dalam buku tersebut menunjukkan adanya beberapa kesamaan antara teks Veda dan Injil. Ia menyimpulkan bahwa Veda merupakan persiapan bagi Injil, dan makna religius yang sudah dipahami dan terbentuk oleh penduduk lokal akan disempurnakan dalam pemaknaan Injil. Contoh lain, misalnya yang dilakukan oleh Listijabudi dalam pembacaan lintas teks antara narasi Yakub di sungai Yabok dengan tradisi mistik Dewa Ruci. Lih. Rasiah S. Sugirtharajah, The Bible and the Third World (Cambridge University Press, 2001), 90 97, https://doi.org/10.1017/CBO9780511612619; Listijabudi, Bergulat Di Tepian: Pembacaan Lintas Tekstual Dua Kisah Mistike (Dewa Ruci \& Yakub Di Yabok) Untuk. Membangun Perdamaian, 257-319. 


\section{KESETARAAN ANTARA PIHAK YANG MENGINJILI DAN DIINJILI}

Salah satu problem yang muncul dari perspektif misi yang elitis dan profesionalis adalah tendensi superioritas dari orang yang menginjili. Tanpa disadari, seseorang bisa menjadi tidak sensitif dan arogan ketika merasa dirinya tahu tentang kebenaran. ${ }^{38}$ Tidak ada yang salah dengan merasa sudah mengetahui kebenaran tetapi problem muncul ketika orang yang diinjili justru dipandang sebagai orang berdosa yang sudah ditakdirkan menjadi penghuni neraka dan bukan sebagai manusia berharga yang seharusnya dikasihi di dalam Kristus. Demi mengupayakan misi yang holistik, para misionaris harus menghindari sikap seperti ini apalagi dalam konteks pertemuan dan interaksi dengan agama-agama lain. Pendekatan superior seperti terlalu beresiko untuk mengundang konflik dan akhirnya penolakan Injil.

Pendekatan poskolonial memberi tahu bahwa cara pandang superior dan inferior seperti ini sejatinya merupakan sebuah oposisi biner dan perlu dilawan karena bersifat hirarkis dan rawan menimbulkan represi. Pendekatan poskolonial kemudian menganjurkan sebuah kesetaraan yang tidak mendiskreditkan satu sama lain atau merasa diri lebih baik dari yang lain. Dalam penginjilan hal ini diterapkan dengan terutama menekankan bahwa semua manusia, termasuk orang yang sudah percaya kepada Kristus sekali pun, masih dan tetap membutuhkan kuasa Injil. ${ }^{39}$ Tidak ada perbedaan hierarki atau kasta antara orang yang sudah menerima Injil dan yang belum. Semuanya sama-sama manusia berdosa yang membutuhkan belas kasihan dan penyelamatan ilahi.

\section{KESIMPULAN}

Sejauh ini dapat disimpulkan bahwa pendekatan poskolonial dapat memberikan penajaman dan perluasan terhadap makna, cakupan dan tugas kerja misi injili. Pendekatan poskolonial juga mendorong pelaku misi injili untuk lebih sensitif dan apresiatif terhadap budaya lokal dan kelompok orang yang mungkin terpinggirkan. Pertanyaan selanjutnya: jika cita-cita integrasi misi-poskolonial injili memang dapat terbentuk, maka bagaimana

38Daniel Lucas Lukito, "Eksklusivisme, Inklusivisme, Pluralisme, Dan Dialog Antar Agama," Veritas: Jurnal Teologi Dan Pelayanan 13, no. 2 (October 1, 2012): 251-79, https://doi.org/10.36421/veritas.v13i2.269.

${ }^{39}$ Keller, Center Church: Doing Balanced Gospel-Centered Ministry in Your City, 52-70; Chan, Evangelism in a Skeptical World: How to Make the Unbelievable News About Jesus More Believable. 
langkah praktisnya? Tentu saja elaborasi dan implementasi gagasan poskolonial dalam praksis misi dapat terjadi secara beragam dalam konteks pelayanan injili yang berbeda-beda pula. Tetapi ada setidaknya dua disposisi umum yang perlu terlebih dahulu diperhatikan dan dipertimbangkan.

Pertama, gereja-gereja atau lembaga-lembaga misi injili mungkin dapat membuka ruang bagi multiplisitas hermeneutis, alih-alih menekankan gagasan makna tunggal khususnya dalam hal pembacaan Alkitab dan konstruksi dogmatika. Asumsi dari makna tunggal itu sendiri bersifat biner: jika ada satu makna yang benar, maka semua yang lain selain itu adalah salah. Rupanya klaim ini perlu dipikirkan ulang. Apakah meyakini adanya sebuah makna atau tafsiran yang solid dan benar harus langsung berarti makna selalu bersifat tunggal dan berjumlah satu? Bukankah justru bisa saja ada lapisan yang lebih dalam atau dimensi yang lebih tebal dan luas dari makna yang sahih? Ini tidak berarti bahwa makna bisa menjadi sangat relatif dan bergerak tanpa standar. Adalah tugas hermeneutika untuk justru menemukan prisma makna yang tebal dan mendalam berdasarkan kaidah konteks yang komprehensif dan bukan hanya menemukan satu dimensi makna dari sudut bidik konteks tertentu (misalnya hanya menemukan makna menurut penulis berdasarkan konteks historis dan kultural masa itu). Jika disposisi hermeneutika sudah tiba pada penghayatan bahwa makna teks sejatinya bisa berupa sebuah bangunan yang mendalam, tebal dan kompleks, maka kemungkinan "kemerdekaan" hermeneutis orang lokal jauh lebih dapat dicapai tanpa perlu dihantui ketegangan antara kontekstualisasi atau sinkretisme serta tafsir benar atau tafsir salah.

Kedua, gereja-gereja atau lembaga-lembaga misi injili mungkin dapat membuka ruang bagi kepemimpinan setara atau setidaknya non-hierarkis. Meskipun tidak dapat terlalu banyak dielaborasi dalam paparan ini, tetapi perlu dicermati bahwa sesungguhya ide kepemimpinan setara adalah ide awal reformasi Protestan yang juga berangkat dari ide Alkitab sendiri yaitu imamat yang rajani (1Ptr. 2:9-10). Kepemimpinan setara atau non-hierarkis tidak berarti semua orang dapat menjadi bebas, liar, tidak terkendali dan tidak mengembangkan nilai-nilai spiritual seperti akuntabel atau menghormati otoritas. Menurut hemat penulis, nilai-nilai seperti akuntabilitas, respek, ketaatan, batasan serta tanggung jawab dalam mengenali dan menjalankan peran merupakan hal-hal yang tidak harus selalu terkait secara langsung dengan hierarki kepemimpinan. Dengan membangun antropologi yang teologis, bahwa semua manusia adalah gambar Allah yang berharga; dan poskolonialis dalam pengertian bahwa semua orang adalah manusia mandiri dan tidak berada dalam "jajahan" 
manusia lain, justru setiap orang dapat memandang dirinya sebagai pribadi yang utuh, mampu berdikari serta memiliki ruang dan tanggung jawab untuk membuat pilihan-pilihan pribadi yang justru dapat diarahkan untuk memilih mengupayakan kemajuan bagi diri dan sesamanya meskipun mensyaratkan harga penundukan diri atau toleransi-toleransi tertentu.

Akan tetapi selain dua hal di atas, ada pula beberapa hal yang perlu dicermati terkait interaksi dan implementasi pandangan poskolonial dalam paradigma dan praksis misi injili. Pertama, setiap pelaku misi-poskolonial perlu cermat bahwa semangat poskolonial adalah meniadakan segala bentuk dominasi dan hegemoni pengetahuan. Ini harus berlaku terhadap gagasan poskolonial itu sendiri. Jangan sampai poskolonialisme malah menjadi kolonialisme baru dan hanya membalikkan biner dari posisi bawah ke atas dan sebaliknya. Poskolonialisme, jika ingin konsisten perlu terusmenerus menyeimbangkan posisi di tengah (in between) dan menjaga hibriditas. Ini menyisakan sebuah pertanyaan: mungkinkah orang yang sudah mengenal Kristus tetap berada dalam posisi antara? Mungkinkah pengikut Kristus menjadi bybrid antara memegang nilai-nilai Kerajaan Allah dan nilai-nilai dunia? Jika mungkin, sejauh mana dan seperti apakah bentukbentuk hibriditasnya? Perlu kajian lebih lanjut mengenai hal ini.

Kedua, seiring dengan globalisasi yang akan semakin melenturkan bahkan mengaburkan lini negara adikuasa dan negara dunia ketiga, mungkinkah ada budaya lokal yang benar-benar lokal atau budaya marjinal yang benar-benar marjinal? Lebih lalu apa dan dari manakah sudut pandang lokal dan asing, Timur dan Barat, dominan dan marjinal itu dibangun? Agaknya poskolonialisme perlu menyadari bahwa globalisasi justru menghasilkan "hibriditas", jika dapat dikatakan demikian yang akan menyulitkan untuk mencari posisi otentik dari kelompok non-dominan yang ingin disuarakan. ${ }^{40} \mathrm{Ke}$ depan pertanyaan yang akan dihadapi adalah siapa yang menjajah siapa?

Ketiga, pendekatan poskolonialisme juga rentan menghasilkan etnosentrisme, atau penekanan sepihak terhadap sudut pandang budaya tertentu. ${ }^{41}$ Berangkat dari kecurigaan terhadap monopoli teks dari penguasa, pendekatan ini kemudian mensyaratkan dekonstruksionisme pada metodologinya. Perhatian akan lebih banyak diberikan pada penemuan sudut pandang budaya lokal yang tersembunyi. Jika tidak hatiFoe?," 11.

${ }^{40}$ Mamahit, "Postcolonial Reading of the Bible: An Asian Evangelical Friend or ${ }^{41}$ Mamahit, 12. 
hati dan kritis, justru pembacaan seperti ini mereduksi teks dari maknanya yang utuh. Jika hal demikian sampai terjadi, maka poskolonialisme akan terjebak dalam cacat hermeneutis yang dikritiknya sendiri. Perlu diingat bahwa semua budaya memiliki limitasi, kelemahan dan titik butanya masing-masing. ${ }^{42}$ Lagipula dalam kaitannya dengan misi, dapatkah Kristus dikotak secara penuh dalam satu budaya atau konteks tertentu?

Jadi kesimpulannya adalah apakah pendekatan poskolonial dapat digunakan dan memberikan sumbangsih dalam paradigma dan praksis misi injili? Tentu saja. Meskipun demikian, perlu diingat bahwa ada keseimbangan-keseimbangan yang harus diupayakan dan dijaga dalam penerapan misi-poskolonial-injili, agar tidak jatuh lagi kepada biner dan hierarki yang justru ingin dientaskan. Mengutip kalimat Ikrar Lausanne yang dicatat di awal tulisan, bahwa keselamatan ilahi membawa penghakiman bagi segala bentuk penindasan, maka semua metodologi dan pendekatan dapat digunakan dengan tetap terbuka untuk menerima "penghakiman" jika sudah berubah menjadi suara opresif lainnya.

\section{DAFTAR PUSTAKA}

Aritonang, Jan S. Berbagai Aliran Di Sekitar Gereja. Jakarta: BPK Gunung Mulia, 1996.

Bebbington, David. Evangelicalism in Modern Britain: A History from the 1730s to the 1980s. Grand Rapids: Baker, 1989.

Buntu, Ivan Sampe. "Membaca Teks Dalam Pandangan Poskolonial: Catatan Kritis Atas Bacaan Terhadap Teks Kitab Suci.” BLA': Jurnal Teologi Dan Pendidikan Kristen Kontekstual 1, no. 2 (December 30, 2018): 179-90. https://doi.org/10.34307/b.v1i2.46.

Carlson, Kent, and Mike Lueken. Renovation of the Church: What Happen When a Seeker Church Discovers Spiritual Formation. Downers Grove: InterVarsity, 2011.

Chan, Sam. Evangelism in a Skeptical World: How to Make the Unbelievable News About Jesus More Believable. Grand Rapids: Zondervan, 2018.

Costas, Orlando E. The Church and Its Mission: A Shattering Critique from the Third World. Wheaton: Tyndale, 1974.

Emmanuel Gerrit Singgih. "Karl Barth, Robert Jewett and the Context of

${ }^{42}$ Mamahit, 12. 
Reformation in Present-Day Indonesia." Asia Journal of Theology 23, no. 1 (2009).

Gandhi, Leela. Postcolonial Theory: A Critical Introduction. London: Allen \& Unswin, 1998.

Harris, Brian. "Beyond Bebbington: The Quest for Evangelical Identity." Churchman 122, no. 3 (2008): 201-20.

Hutagalung, Toar Banua. "Antropologi Teologis Melalui Perspektif Poskolonial." Theovlogy Channel, 2020. https://www.youtube.com/watch?v=Xy4XVJ12aq0.

"Dishoming Space: Toward an Embodied Decolonial Pneumatology.” Garret-Evangelical Theological Seminary, 2021.

Intan, Benyamin Fleming. "Misi Kristen Di Indonesia: Kesaksian Kristen Protestan." Societas Dei: Jurnal Agama Dan Masyarakat 2, no. 2 (October 24, 2017): 325. https://doi.org/10.33550/sd.v2i2.21.

Jethani, Skye. Immeasurable: Reflections on the Soul of Ministry in the Age of Church, Inc. Chicago: Moody, 2017.

Keller, Catherine. Postcolonial Theologies: Divinity and Empire. St. Louis: Chalice, 2004.

Keller, Timothy. Center Church: Doing Balanced Gospel-Centered Ministry in Your City. Grand Rapids: Zondervan, 2012.

Kristiawan, Danang. "INTERPRETASI ALKITAB POSTKOLONIAL DI ASIA: BELAJAR DARI SUGIRTHARAJAH.” Gema Teologi 33, no. 1 (2009): 1-21. http://journaltheo.ukdw.ac.id/index.php/gema/article/view/33.

Kusmari, Yani. "Teori Poskolonial: Suatu Kajian Tentang Teori Poskolonial Edward W. Said." Departemen Pendidikan Sejarah, 2019.

Listijabudi, Daniel K. Bergulat Di Tepian: Pembacaan Lintas Tekstual Dua Kisah Mistik (Dewa Ruci \& Yakub Di Yabok) Untuk Membangun Perdamaian. Jakarta: Gunung Mulia, 2019.

—. "Pembacaan Alkitab Liberatif, Kontekstual, Postkolonial (KisiKisi Sederhana, Kunci Heuristik Dan Contohnya)." In Meretas Diri, Merengkuh Liyan, Berbagi Kehidupan, edited by Paulus S. Widjaja and 
Wahju S. Wibowo, 3-24. Jakarta: BPK Gunung Mulia, 2020.

Lukito, Daniel Lucas. "Eksklusivisme, Inklusivisme, Pluralisme, Dan Dialog Antar Agama." Veritas: Jurnal Teologi Dan Pelayanan 13, no. 2 (October 1, 2012): 251-79. https://doi.org/10.36421/ veritas.v13i2.269.

Maggay, Melba Padilla. Transformasi Masyarakat: Refleksi Keterlibatan Sosial Kristen. Edited by Johan Hasan. Jakarta: Ergon Radix Integrita, 2004.

Mamahit, Ferry Y. "Perjanjian Lausanne 1974: Revitalisasi Missio Dei Evangelikal.” Malang, 2017.

- "Postcolonial Reading of the Bible: An Asian Evangelical Friend or Foe?” Malang, 2017.

_. "Studi Pascakolonial Dan Evangelikalisme: Kawan Atau Lawan?" Theovlogy Channel, 2019. https://www.youtube.com/watch?v= 7 faybR4gwbg.

Mamahit, Ferry Yefta. "Globalisasi, Gereja Injili Dan Transformasi Sosial." Veritas: Jurnal Teologi Dan Pelayanan 6, no. 2 (October 1, 2005): 25578. https://doi.org/10.36421/veritas.v6i2.151.

Peters, George W. A Biblical Theology of Missions. Chicago: Moody, 1974.

Platt, David. Radical Together. Colorado: Multnomah, 2011.

Sawant, Datta G. "Perspectives on Postcolonial Theory: Said, Spivak and Bhabha," 2015. https://www.researchgate.net/publication/ 271633479.

Sianipar, Gading. "Mendefinisikan Pascakolonialisme?: Pengantar Menuju Wacana Pemikiran Pascakolonialisme." In Hermeneutika Pascakolonial, edited by Mudji Sutrisno and Hendar Putranto. Yogyakarta: Kanisius, 2004.

Sidharta, Leonard. “Spiritualitas Injili.” Jakarta, 2017.

Spivak, Gayatri Chakravorty. "Can the Subaltern Speak?: Speculations on Widow Sacrifice," n.d. http://abahlali.org/files/Can_the_subaltern _speak.pdf.

Sugirtharajah, Rasiah S. The Bible and the Third World. Cambridge University Press, 2001. https://doi.org/10.1017/CBO9780511612619. 
Sutrisno, Mudji. "Diri Dan 'The Other." In Hermeneutika Pascakolonial: Soal Identitas. Yogyakarta: Kanisius, 2004.

Tampubolon, Yohanes Hasiholan. "Misi Gereja Di Era Kapitalisme Global: Eksplorasi Pelayanan Misi Yesus.” Societas Dei: Jurnal Agama Dan Masyarakat, 2020. https://doi.org/10.33550/sd.v7i2.137.

“The Cape Town Commitment," n.d. https://www.lausanne.org/content /ctcommitment\#capetown.

“The Lausanne Covenant," n.d. https://www.lausanne.org/content /covenant/lausanne-covenant\#cov.

“The Manila Manifesto," n.d. https://www.lausanne.org/content/ manifesto/the-manila-manifesto.

Wijanarko, Robertus. "POSKOLONIALISME1 DAN STUDI TEOLOGI Sebuah Pengantar." Studia Philosophica et Theologica 8, no. 2 (2008): 123-33. https://doi.org/https://doi.org/10.35312/spet.v8i2.102.

Wilson, Jared C. The Gospel Driven Church: Uniting Church-Growth Dreams with the Metrics of Grace. Grand Rapids: Zondervan, 2019.

Wim, Chandra. "The Chronicles of Evangelicalism: Sebuah Pengantar Historis Terhadap Gerakan Evangelikal." Veritas : Jurnal Teologi Dan Pelayanan 12, no. 2 (October 1, 2011): 185-207. https://doi.org/10.36421/veritas.v12i2.249.

Winter, Ralph D. "The Two Structures of God's Redemptive Mission." Missiology: An International Review 2, no. 1 (January 1, 1974): 121-39. https://doi.org/10.1177/009182967400200109.

CARMia MARgaret, adalah Hamba Tuhan di GKIm Hosana Bandung. Beliau menyelesaikan program Sarjana Teologi di STT SAAT, Malang, dan sekarang sedang menyelesaikan program Magister Teologi di sekolah yang sama. 